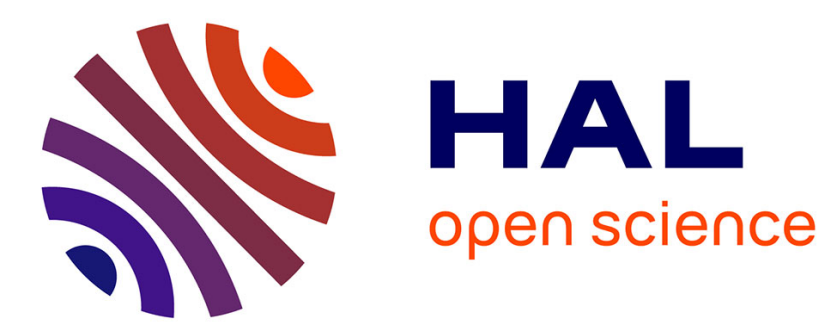

\title{
SPECIFIC HEAT ANOMALY IN THE NEIGHBOURHOOD OF A FERRO-PARAELECTRIC TRANSITIONS
}

\author{
M. C. Bernard, J. Perrigot, Murielle Richard, L. Eyraud
}

\section{- To cite this version:}

M. C. Bernard, J. Perrigot, Murielle Richard, L. Eyraud. SPECIFIC HEAT ANOMALY IN THE NEIGHBOURHOOD OF A FERRO-PARAELECTRIC TRANSITIONS. Journal de Physique Colloques, 1972, 33 (C2), pp.C2-94-C2-96. 10.1051/jphyscol:1972229 . jpa-00214965

HAL Id: jpa-00214965

https://hal.science/jpa-00214965

Submitted on 1 Jan 1972

HAL is a multi-disciplinary open access archive for the deposit and dissemination of scientific research documents, whether they are published or not. The documents may come from teaching and research institutions in France or abroad, or from public or private research centers.
L'archive ouverte pluridisciplinaire HAL, est destinée au dépôt et à la diffusion de documents scientifiques de niveau recherche, publiés ou non, émanant des établissements d'enseignement et de recherche français ou étrangers, des laboratoires publics ou privés. 
$C_{\mathrm{p}_{1}}=\Delta W_{1} /\left(T_{2}-T_{1}\right)\left(T_{1}<T_{2}<T_{\mathrm{c}}\right)$ est plus importante que celle observée lorsque l'on redescend à $T_{1}$ soit $C_{\mathrm{p}_{2}}=\Delta W_{2} /\left(T_{2}-T_{1}\right)$ ou celle mesurée lorsque l'on remonte à $T_{2}: C_{\mathrm{p}_{3}}=\Delta W_{3} /\left(T_{2}-T_{1}\right)$.

La valeur de $C_{\mathrm{p}}$ obtenue dans les deux derniers cas (et aussi lors des cycles suivants) est toujours identique et peut être appelée chaleur spécifique réversible $C_{\mathrm{pR}}$ du matériau pour l'intervalle de température $\left(T_{1}, T_{2}\right)$. La différence $\left(C_{\mathrm{p}_{1}}-C_{\mathrm{pR}}\right) \Delta T$ semble correspondre à une chaleur latente qui n'est pas restituée lors des cycles en raison de l'hystérésis thermique de la transition (environ $10^{\circ} \mathrm{C}$ ).

Ainsi pour le titanate de plomb (Fig. 2) on peut constater que $C_{\mathrm{p}_{1}}$ atteint $0,1 \mathrm{cal} / \mathrm{g}{ }^{\circ} \mathrm{C}$ à la température de transition $T_{\mathrm{c}}=488^{\circ} \mathrm{C}$ (montée de température) alors que $C_{\mathrm{pR}}$ n'excède pas $0,14 \mathrm{cal} / \mathrm{g}{ }^{\circ} \mathrm{C}$. Par contre en dessus de $T_{\mathrm{c}}$ on a $C_{\mathrm{p} 1}=C_{\mathrm{pR}}=0,1 \mathrm{cal} / \mathrm{g}{ }^{\circ} \mathrm{C}$. On peut évaluer

$$
L=\int_{0}^{T \mathrm{c}}\left(C_{\mathrm{p}_{1}}-C_{\mathrm{pR}}\right) \mathrm{d} T=360 \mathrm{cal} / \mathrm{mole}
$$

qui correspond à la surface $S_{1}$ et

$$
\Delta H=\int_{0}^{T \mathrm{c}} \Delta C_{\mathrm{p}} \mathrm{d} T=500 \mathrm{cal} / \mathrm{mole}
$$

surface $S_{1}+S_{2}$.

$\Delta C_{\mathrm{p}}$ représentant l'anomalie totale de $C_{\mathrm{p}}$ par rapport aux valeurs obtenues en dessous de $430^{\circ} \mathrm{C}$ dans la phase antiferroélectrique. Ce résultat concorde avec ceux obtenus précédemment [3], [7] au moyen d'appareils d'analyse thermique différentielle.

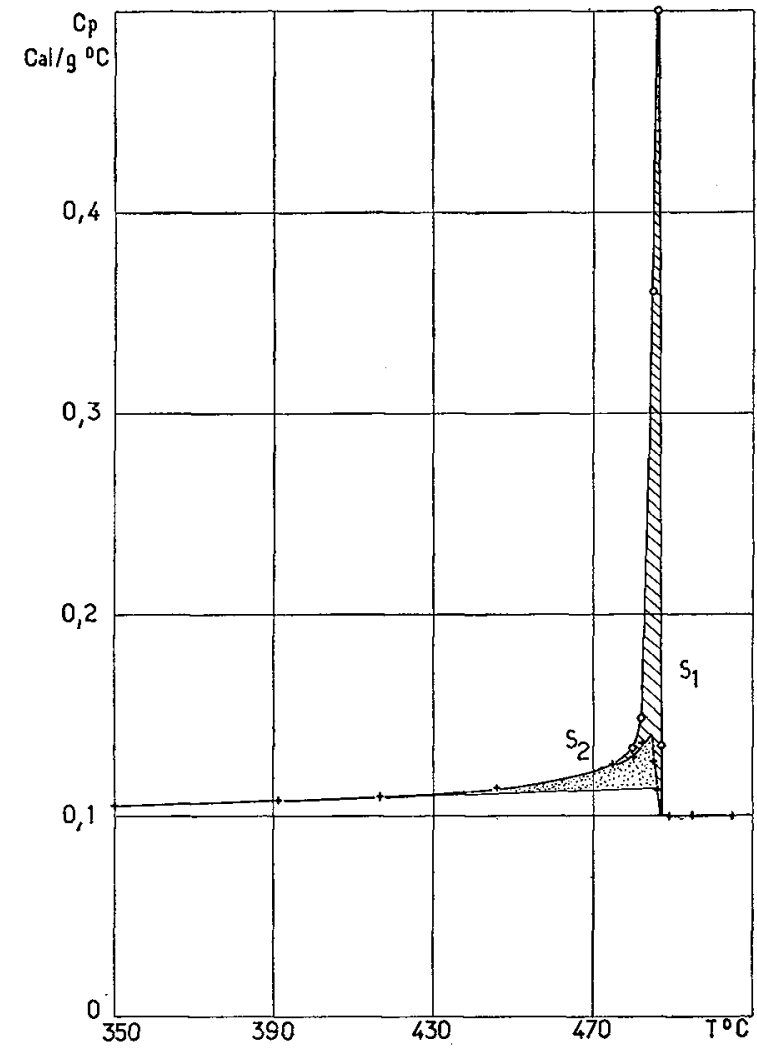

FIG. 2. - Chaleur spécifique de $\mathrm{PbTiO}_{3}$ céramique. Courbe + chaleur spécifique réversible $C_{p R}$. Courbe 0 chaleur spécifique obtenue à la première montée : $S_{1}$ aire associée à $L ; S_{1}+S_{2}$ aire associée à $\Delta H$.

La température de transition en descente de température est $T_{c}^{\prime}=479^{\circ} \mathrm{C}$ et des phénomènes analogues sont observables.

\title{
SPECIFIC HEAT ANOMALY IN THE NEIGHBOURHOOD OF A FERRO-PARAELECTRIC TRANSITIONS
}

\begin{abstract}
We report our measurements of specific heat variations versus temperature in the neighbourhood of ferro-paraelectric transitions. Two typical exemples have been chosen : T. G. S. for second order transition and $\mathrm{PbTiO}_{3}$ for first order transition. The occurrence of a thermal hysteresis in the second case is used to evaluate the latent heat associated with the transition.
\end{abstract}

It is known that when you raise the temperature through a ferro-paraelectric or an antiferro-paraelectric transition an important endothermic effect can be detected [1], [2]. This effect, which becomes exothermic when you lower temperatures, spreads over a range which can vary from a few degrees to several tens of degrees according to the nature of the material under study. Contributing to this phenomenon among others are : the thermal effect which goes together with the off-set or the on-set of spontaneous polarization ; the one resulting from contraction or dilatation of the unit cell ; the one resulting form the appearance or the disappearance of a domain structure etc... [3], [4].

One of the most important problems which still remains to be solved concerning these transitions is to know if, from a thermodynamic point of view, they can be considered as being of the first or the second order. In other words : is the above-said thermal effect only due to a gradual change in the specific heat, or is there a latent heat associated with these transitions ? The answer to that question would be easy to find if the material under study were monocrystals 
with a well known transition temperature : for instance for T. G.S. crystals there is a regular rise of the specific heat under $T_{\mathrm{c}}=49^{\circ} \mathrm{C}$ and an abrupt fall of its value can be observed at the Curie-temperature, but no anomalous thermal effect in the neighbourhood of $T_{\mathrm{c}}$ can be detected (Fig. 1). We may therefore conclude that this transition belongs to the second order.

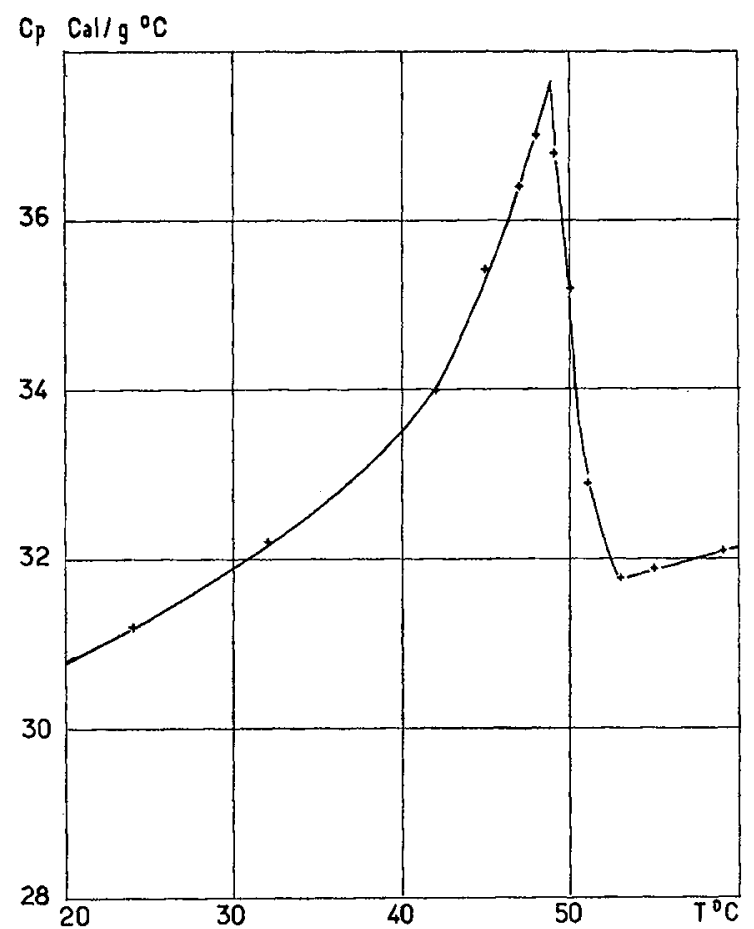

Frg. 1. - Specific heat variation of T. G. S.

On the contrary, when we have to study fritted ceramic samples of lead zirco-titanate there occur internal strains within the samples which spread the transition over several degrees, and then it is very difficult to distinguish a latent heat from a progressive change of the specific heat. However we have been able with the help of an apparatus specially designed for that kind of measurements to contribute a new approach to the study of these phenomena [5], [6].

This apparatus enabled us to put a sample through loops of temperatures neighbouring $T_{\mathrm{c}}$, and to measure $C_{\mathrm{p}}=\Delta W / \Delta T$ corresponding to increases or decreases in temperature of $T=1$ to $2^{\circ} \mathrm{C}$. We could then observe that when you raise the temperature for the first time from $T_{1}$ to $T_{2}$ (in the neighbourhood of $T_{\mathrm{c}}$ ) the specific heat measured $C_{\mathrm{p}}=W_{2} /\left(T_{2}-T_{1}\right)$ is more important than the one observed when you lower the temperature from $T_{2}$ to $T_{1}$, or than the one observed when you rise again from $T_{1}$ to $T_{2}$.

The value of $C_{\mathrm{p}}$ measured in the course of the last two experiments, which is found to be the same, can be called reversible and can be considered as the true specific heat $\left(C_{\mathrm{pR}}\right)$.
The difference $\left(C_{\mathrm{p}_{1}}-C_{\mathrm{pR}}\right) \Delta T$ is likely to correspond to a latent heat which did not appear in the course of the later experiments because of the thermal hysteresis of these transitions. In some cases that hysteresis can reach up to ten degrees $C$.

For instance in the case of $\mathrm{PbTiO}_{3}$ (Fig. 2) we have :

$T_{\mathrm{c}}=488^{\circ} \mathrm{C}$ when you raise the temperature ;

$T_{\mathrm{c}}^{\prime}=479^{\circ} \mathrm{C}$ when you lower it;

$C_{\mathrm{p}_{1}} \# 0,5 \mathrm{cal} / \mathrm{g}^{\circ} \mathrm{C}$ between 486 and $488{ }^{\circ} \mathrm{C}$;

$C_{\mathrm{pR}} \# 0,14 \mathrm{cal} / \mathrm{g}{ }^{\circ} \mathrm{C}$ for the same range of temperature ;

$C_{\mathrm{p}_{1}}=C_{\mathrm{pR}} \# 0,1 \mathrm{cal} / \mathrm{g}{ }^{\circ} \mathrm{C}$ just above $T_{\mathrm{c}}$.

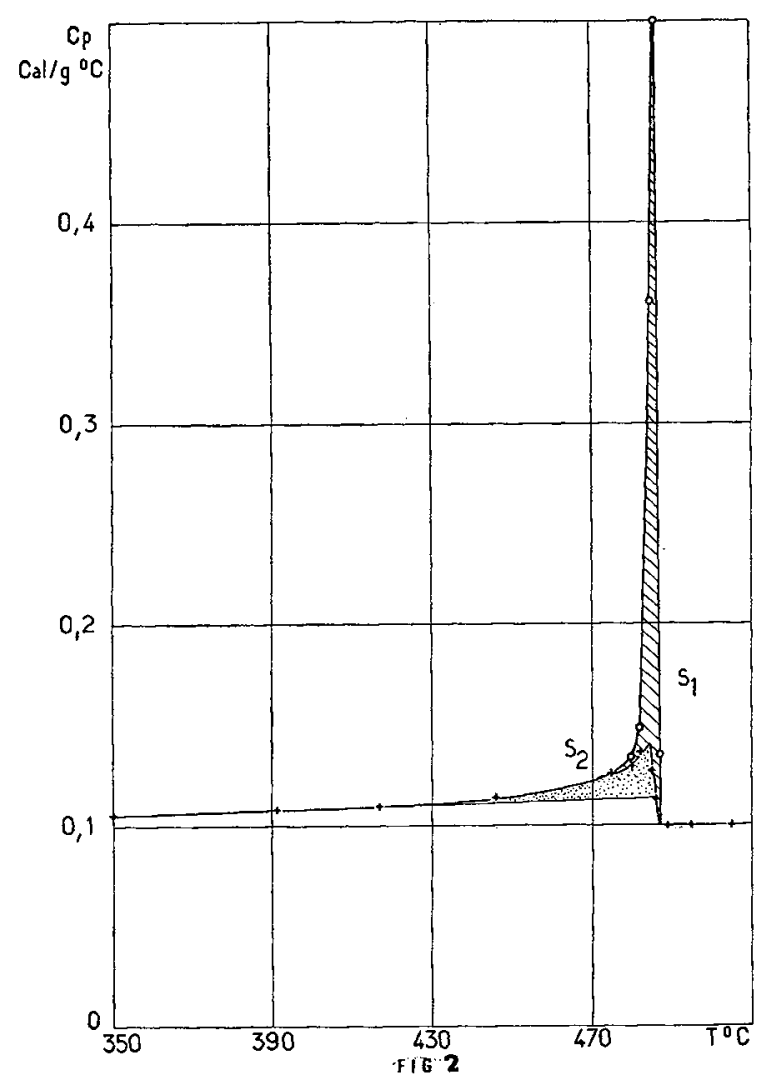

Fig. 2. - Specific heat variation of $\mathrm{PbTiO}_{3}$. Curve + : reversible part of $C_{\mathrm{p}}=C_{\mathrm{pR}}$. Curve 0 : value of $C_{\mathrm{p}}$ measured during the first raising of temperature : $S_{1}$ area associated with $\langle l\rangle$; $S_{1}+S_{2}$ area associated with « $\Delta H »$.

We can also evaluate

$$
l=\int_{0}^{T \mathrm{c}}\left(C_{\mathrm{p}_{1}}-C_{\mathrm{pR}}\right) \mathrm{d} T=360 \mathrm{cal} / \mathrm{mole}
$$

whereas before now we could only know the whole thermal effect [3], [7]

$$
\Delta H=\int_{0}^{T \mathrm{c}} \Delta C_{\mathrm{p}} \mathrm{d} T \neq \neq 500 \mathrm{cal} / \mathrm{mole}
$$

in which formula $\Delta C_{\mathrm{p}}$ stands for the specific heat anomaly. 


\section{References}

[1] Shirane (G.) and Hoshino (S.), J. Phys. Soc. Japan, $1951,6,265$.

[2] Hoshino (S.), Mitsui (T.), Jona (F.), Pepinsky (R.), Phys. Rev., 1957, 107, 1255.

[3] Richard (M.), Thèse Lyon, 1963.

[4] Eyraud (L.), Diélectriques solides anisotropes et Ferroélectricité Gauthier-Villars, 1967.
[5] Bernard (M.), Mesures des chaleurs spécifiques dans la gamme $25-600^{\circ} \mathrm{C}$, Journées de Calorimétrie de Lyon, mai 1970.

[6] Bernard (M.), Roux (A.), Etude calorimétrique de quelques phénomènes irréversibles. Soc. Chim. de France, Rouen, mai 1970.

[7] Fetiveau (Y.), Thèse Lyon, 1969. 